DOI https://doi.org/10.30525/978-9934-26-180-0-52

\title{
ПРОБЛЕМИ ВИВЧЕННЯ ЯПОНСЬКОЇ МОВИ НА МАТЕРІАЛІ КОМІКСІВ МАНІА
}

\author{
Кравець М. О. \\ старший викладач кафедри порівняльної філології східних \\ та англомовних країн \\ Дніпровський начіональний університет імені Олеся Гончара \\ м. Дніпро, Украӥна
}

Оскільки молодь завжди складала основний масив здобувачів освіти, науковці-методисти, які працюють у сходознавчій царині, часто звертаються до ідеї викладання японської мови на матеріалі коміксів манга. Серед переваг такого підходу виокремлюють, зокрема, наступні: підвищення мотивації, активація попередніх знань і робота з текстами, які репрезентують автентичне японське розмовне мовлення [1].

Якщо йдеться про мотивацію, то тут важливу роль відіграє зацікавленість студентів у матеріалі, з яким вони працюють протягом аудиторних занять та самостійної роботи, а також можливість встановлення досяжних цілей навчання, як-от освоєння певних граматичних конструкцій та лексичної бази для прочитання улюбленої манга чи принаймні розуміння окремих іiї уривків.

Активація попередніх знань може проявлятися в освоєнні навчального лінгвістичного матеріалу за рахунок творів манга, прочитаних у перекладі, тож студент, маючи певні знання про сюжет, героїв, культурний бекграунд, може вільніше почуватися, читаючи оригінальний текст, віднаходячи значення незнайомих слів та граматичних конструкцій зі знайомого контексту [1].

Велика кількість жанрів та варіативність характеристик персонажів може стати підставою для використання манга в якості навчальних матеріалів для набуття перекладацьких компетенцій. Перекладачі японських коміксів повсякчас стикаються із широким спектром перекладацьких проблем, як-от безеквівалентна лексика, звуконаслідування, гра слів, гумор. Так Х. Фурухата-Тернер припускає, що доречно використовувати манга під час викладання перекладу з японської мови [1].

Манга також є одним із небагатьох ресурсів, який можна використовувати в якості навчального матеріалу для вивчення японського розмовного мовлення та його особливостей, що проявляються у вигляді гендерно 
диференційованого мовлення, мовних проявів шанобливості та скромності, тощо.

Втім слід розрізняти навчальні матеріали, в основі яких лежить манга, оскільки в Японії це слово має більш широке значення, яке охоплює не лише окремий впізнаваний жанр, але й може означати будь-яку історію, розказану за допомогою ілюстрацій, тобто - комікс. На японському видавничому ринку широко представлені підручники, в основі яких лежить манга, але це не завжди будуть уривки із відомих серед молоді всього світу творів. У таких навчальних матеріалах комікси можуть подаватися як у вигляді ілюстративного, допоміжного матеріалу, так і бути наскрізною історією, яка матиме продовження у кожному наступному розділі [2].

Проте, незважаючи на те, що подібні підручники укладачі позиціонують як повноцінні посібники для вивчення японської мови, як правило, лінгвістичний матеріал у них представлений фрагментарно. Позитивним є висвітлення культурних аспектів, але на тлі перевантаженості реаліями тексти вміщують різнорівневу лексику й граматику, що ускладнює їх розуміння тими, хто навчається. До того ж нівелюються основні переваги вивчення мови на матеріалі манга. Не дивлячись на оригінальність історій, представлених у таких посібниках, більшість із них $\epsilon$ адаптованими для іноземців, які вивчають японську мову, а отже втрачається і автентичність мови, й упізнаваність сюжету, яка могла б допомогти у розуміння змісту. У тих же випадках, коли для ілюстрування вживання граматики, ономатопоетичних виразів чи ієрогліфіки укладачі все ж використовують уривки із популярної манга, одного чи двох фреймів може виявитися недостатньо для ефективного засвоєння матеріалу та стимулювання мотивації. Не менш важливим $є$ і фактор плинності масової культури - манга, яка знаходиться на піку популярності в рік виходу підручника друком, може швидко втратити іï, i не буде настільки дієвим стимулом для студентів, які користуватимуться підручником за кілька років після видання.

Якщо ж говорити про використання оригінальної манга в якості навчальних матеріалів для формування компетенції читання, вивчення окремих граматичних (частки, розмовні скорочення) або лексичних одиниць (наприклад, ономатопеї), то викладач може також зіткнутися 3 рядом проблем, пов'язаних із особливостями японської мови та жанровими характеристиками самих коміксів.

Відомо, що японський мовленнєвий етикет тісно пов'язаний iз концептами そと й うち-«свій» та «чужий», тому вивчення мови у вищій школі починають, як правило, із нейтрально-ввічливих форм для того, 
щоб здобувач освіти одразу на початку навчального процесу міг здійснювати нескладні акти комунікації з незнайомими японцями, не виявляючи при цьому фамільярності чи ворожості. Форми, властиві для неформального спілкування, вивчаються дещо пізніше.

Натомість у популярних манга поширеними $\epsilon$ сюжети, пов'язані із конфліктами героїв, їхніми суперечками, протистоянням на різних рівнях, чим пояснюється поширеність вживання грубих наказових форм, підсилювальних часток, емфатичних подвоєнь чи фонетичних трансформацій. 3 одного боку, це яскравий ілюстративний матеріал для вивчення живого природнього мовлення. Як правило, за рахунок повторюваності та емоційного забарвлення ці фрази, які містять згадані мовленнєві явища, легко запам'ятовуються тими, хто вивчає мову. Але з іншого боку, викладач має чітко окреслити ряд соціолінгвальних ситуацій, у яких можуть вживатися ті чи інші вирази, просити студентів самостійно описувати й аналізувати обставини, за яких та чи інша репліка вимовляється персонажем, щоб навчити доречному використанню набутих знань.

Іще однією задачею викладача в разі обрання манга в якості основи для створення навчальних матеріалів $\epsilon$ формування відповідного списку творів, які б демонстрували практичне використання різностатевого мовлення, відмінних мовленнєвих жанрів та регістрів. Стереотипність персонажів японських коміксів може створювати сприятливі обставини, за яких майбутні сходознавці можуть робити узагальнення щодо особливостей мовлення людей певного віку, статусу, характеру, тощо.

Корисним може бути досвід діахронічного підходу до вивчення особливостей японської мови, представленої в манга. Порівнюючи мовлення героїв коміксів, створених у різні епохи, ті, хто вивчають японську мову, можуть доходити певних висновків щодо розвитку та змін японського розмовного мовлення протягом обраного часового відрізку.

Підсумовуючи, можна зазначити, що манга може бути корисним інструментом для вивчення японської мови й японського розмовного мовлення зокрема. Проте навчання має відбуватися за умов чіткого планування та контролю з боку викладача для того, щоб здобувачі освіти навчилися правильно визначати контекст та соціолінгвальні ситуації використання певних граматичних конструкцій та лексичних одиниць задля запобігання їх недоречного використання.

\section{Література:}

1. H. Furuhata-Turner. Use of Comics Manga as a Learning Tool to Teach Translation of Japanese. JLTL, Vol. 3, No. 2 URL: https://www.academia.edu/ 
12689233/Use_of_Comics_Manga_as_a_Learning_Tool_to_Teach_Translatio n_of_Japanese._JLTL_Vol.3_No.2 (дата звернення 23.12.2021)

2.【マンガ教材】日本語教育の授業に漫画を取り入れるアイデア URL: https://edujapa.com/mikke/level/1/mangainclass/ (дата звернення 23.12.2021)

DOI https://doi.org/10.30525/978-9934-26-180-0-53

\title{
ЕФЕКТИВНІ МЕТОДИ НАВЧАННЯ АНГЛІЙСЬКОЇ МОВИ У СУЧАСНІЙ ШКОЛІ
}

\author{
Толкова Т. М. \\ кандидат педагогічних наук, \\ незалежний дослідник
}

м. Кам'янецьь-Подільський, Хмельницька область, Украӥна

Актуальними завданнями сучасної школи є розвиток та формування творчої особистості, пошук ефективних шляхів навчання, розвиток пізнавальних інтересів дитини, підвищення мотивації до вивчення мови. Як показує практика, за останні роки, суттєво змінюються підходи до викладання англійської мови у школах. Традиційні методи втрачають свої позиції в порівнянні з новими, інноваційними, цікавими та сприйнятливими для дітей методами викладання англійської мови.

Вивченню інтерактивних методів навчання та виховання у системі освіти присвячені праці А. Алексюка, І. Балицької, Т. Бичківської, О. Вєтохова, М. Кларіна, Ю. Кузнецової, Л. Пироженко, О. Пометун, В. Редька, С. Шевченка.

Сутність інтерактивного навчання у тому, що навчальний процес відбувається за умов постійної, активної взаємодії всіх учнів. Це співнавчання, взаємонавчання (колективне, групове, навчання у співпраці), де i учень, і вчитель $є$ рівноправними, рівнозначними суб'єктами навчання, розуміють, що вони роблять, рефлексують 3 приводу того, що вони знають, вміють і здійснюють. Організація інтерактивного навчання передбачає моделювання життєвих ситуацій, використання рольових ігор, вирішення проблеми на основі аналізу обставин та відповідної ситуації [3, с. 7].

На уроках англійської мови для передачі навчальної інформації найчастіше використовується лекційний метод навчання (lecture). 